\title{
STEREOLOGICAL QUANTITATION OF LEYDIG AND SERTOLI CELLS IN THE TESTIS FROM YOUNG AND OLD MEN
}

\author{
PETER M PETERSEN ${ }^{1,2}$ AND BENTE PAKKENBERG ${ }^{2,3}$ \\ ${ }^{1}$ Department of Growth and Reproduction, Copenhagen University Hospital, Rigshospitalet, 2100 Copenhagen $\emptyset$, \\ ${ }^{2}$ Neurological Research Laboratory, Bartholin Institute, Kommunehospitalet, Øster Farimagsgade 5, 1399 \\ Copenhagen K, ${ }^{3}$ Stereological Research Laboratory, Aarhus University, 8000 Århus C, Denmark \\ (Accepted September 9, 2000)
}

\begin{abstract}
One of the newer stereological methods, the optical fractionator, was applied to the study of the effects of ageing on the human testis. The estimated total number of Sertoli and Leydig cells per testis in men younger than 30 years were $430 \times 10^{6}(\mathrm{CV}=\mathrm{SD} /$ mean $=0.35)$ and $117 \times 10^{6}(\mathrm{CV}=0.53)$, respectively, while in men older than 50 years the estimated total Sertoli cell number was $266 \times 10^{6}(\mathrm{CV}=0.46)$ and the mean Leydig cell number $83 \times 10^{6}(\mathrm{CV}=0.53)$. The difference between the number of Sertoli cells in men younger than 30 years compared with men older than 50 years was close to statistical significance $(p=0.052)$ while no differences was found in total Leydig cell number $(\mathrm{p}=0.22)$.
\end{abstract}

Keywords: Leydig cells, Sertoli cells, stereology.

\section{INTRODUCTION}

The process of ageing and the changes in different tissues with age have been in focus during the past decade because the number of healthy elderly people has been increasing in many countries. The effects of ageing on testicular function have been widely discussed, and it is generally accepted that androgen insufficiency with increasing gonadotropins evolves in old men (Murray and Meacham 1993; Haidl et al., 1996). One aspect has been the application of androgen substitution therapy in old men. However, only few studies have concentrated on physiological and histologic changes with ageing. A study of men and their grandfathers showed surprisingly small differences in semen quality and reproductive hormones (Nieschlag et al., 1982) while other studies have indicated more obvious differences (Murray and Meacham 1993). Histologic investigations have indicated decreasing Sertoli cell number and Leydig cell number with increasing age (Kaler and Neaves, 1978; Neaves et al., 1985; Paniagua et al., 1987; Johnson et al., 1984). However, the reports are still conflicting, (Murray and Meacham, 1993). Thus, more basic knowledge on the effects of ageing on the testis is needed. We have applied the stereological tool the optical fractionator (Gundersen et al., 1988;
West et al., 1991) which has proven to be an efficient stereological method for estimating the total number of Sertoli and Leydig cells (Gundersen et al., 1988; Petersen et al., 1996). The great advantage of this method is that no assumptions are required about shape, size or orientation of the cells or shrinkage of the organ during histological processing.

\section{AIM}

The aim of the study was to investigate the effect of ageing on the number of Sertoli and Leydig cells in human testes by use of the optical fractionator principle.

\section{MATERIAL}

Right or left testis from each of fourteen males, eight males younger than 30 years (16-30) and six males older than 50 years (53-78), was selected systematically at random (Table 1). All testes from the young men and two of the testes from the older males were sampled from cases who had been taken to the Department of Forensic Medicine in Copenhagen due to sudden, unexpected death, while the remaining testes from old males were obtained at routine autopsy. The cause of death is shown in (Table 1). 


\section{METHODS}

1) A known fraction of the tissue was sampled systematically at random from each testis in a careful stepwise sampling procedure: a) Each testis was cut into 4-mm-thick slaps, providing 8 12 slaps; b) Every $2^{\text {nd }}-3^{\text {rd }}$ slap was sampled systematically randomly and cut into 4-mm-thick bars providing $6-10$ bars; c) every $2^{\text {nd }}-3^{\text {rd }}$ bar was sampled and cut into cubes; d) every $4^{\text {th }}$ to $6^{\text {th }}$ of these cubes (approximately 8 - 10 cubes) were sampled.

2) The sampled tissue was embedded in 2hydroxy-methacrylate (Technovit $7100 \AA$ ) and stained throughout with hematoxylin eosin where the Leydig cells and Sertoli cells can be recognised. These cell types was easily recognised also in tissue fixed in formalin when embedded in plastic, in contrast to testicular tissue fixed in formalin and embedded in paraffin.

3) The blocks of methacrylate, each containing 8-10 cubes of testicular tissue, were cut exhaustely into $40-\mu \mathrm{m}$-thick sections.
4) Approximately 10 sections were sampled from each testis and the optical fractionator principle used to estimate the total number of Sertoli and Leydig cells in a known fraction of the tissue. To avoid bias from cutting artefacts a disector height of $15 \mu \mathrm{m}$ was chosen. By this sampling procedure the coefficient of error $(\mathrm{CE}=$ $\mathrm{SEM} /$ mean) at each sampling level is estimated and kept below $10 \%$.

5) Approximately 150 of each cell type were counted per testis.

6) The total numbers of Sertoli and Leydig cells were estimated by multiplication of the number of sampled cells by the inverse of the sampling fraction. For example in one testis every $2^{\text {nd }}$ slap, every $3^{\text {rd }}$ bar, every $6^{\text {th }}$ cube, and every $12^{\text {th }}$ methacrylate section were sampled and counting of Leydig cells was performed in 1/4973 of the sampled tissue section. Thus the global sampling fraction was 1: $(2 \times 3 \times 6 \times 12 \times 4973)$. The estimated number of Leydig cells was equal to the inverse of the global sampling fraction times the number of sampled Leydig and Sertoli cells. For further details, see Petersen et al. 2000.

Table 1. Cause of death, age, fixation data and number of Sertoli and Leydig cells in young and old males.

\begin{tabular}{|c|c|c|c|c|c|c|c|c|c|}
\hline$\overline{\text { Side }}$ & $\begin{array}{l}\text { Cause of } \\
\text { death }\end{array}$ & $\begin{array}{l}\text { Time from } \\
\text { death to } \\
\text { processing } \\
\text { (days) }\end{array}$ & Fixative & $\begin{array}{l}\begin{array}{l}\text { Age } \\
\text { (years) }\end{array}\end{array}$ & $\begin{array}{l}\text { Weight } \\
\text { (gr.) }\end{array}$ & $\begin{array}{l}\text { Number of } \\
\text { Sertoli cells } \\
\text { counted }\end{array}$ & $\begin{array}{l}\text { Total Sertoli } \\
\text { cell number } \\
\left(10^{6}\right)\end{array}$ & $\begin{array}{l}\text { i Number of } \\
\text { Leydig cells } \\
\text { counted }\end{array}$ & $\begin{array}{l}\text { Total Leydig } \\
\text { cell number } \\
\left(10^{6}\right)\end{array}$ \\
\hline $\begin{array}{l}\text { Left } \\
\end{array}$ & Sud & 1 & $\mathrm{~F}$ & 16 & 13 & 292 & 665 & 103 & 47 \\
\hline Right & Sud & - & $\mathrm{F}$ & 18 & 22 & 123 & 281 & 94 & 43 \\
\hline Left & Sud & - & $\mathrm{F}$ & 18 & 19 & 344 & 388 & 233 & 53 \\
\hline Left & Sud & 3 & $\mathrm{~F}+\mathrm{A}$ & 22 & 19 & 124 & 400 & 237 & 168 \\
\hline Right & Sud & 2 & $\mathrm{~F}$ & 24 & 19 & 113 & 253 & 143 & 65 \\
\hline Left & Sud & 3 & $\mathrm{~F}+\mathrm{A}$ & 28 & 13 & 158 & 318 & 251 & 111 \\
\hline Left & Sud & 1 & $F+A$ & 29 & 19 & 371 & 571 & 323 & 75 \\
\hline Left & Sud & 2 & $\mathrm{~S}$ & 30 & 23 & 303 & 564 & 256 & 72 \\
\hline $\begin{array}{l}\begin{array}{l}\text { Mean } \\
\text { (range) }\end{array} \\
\end{array}$ & & & & $\begin{array}{l}23.1 \\
(16-30) \\
\end{array}$ & $\begin{array}{l}18.4 \\
(13-23) \\
\end{array}$ & $\begin{array}{l}228 \\
(123-371) \\
\end{array}$ & $\begin{array}{l}430 \\
(253-665) \\
\end{array}$ & $\begin{array}{l}205 \\
(94-323) \\
\end{array}$ & $\begin{array}{l}117 \\
(43-168) \\
\end{array}$ \\
\hline$\overline{\text { Right }}$ & Sud & 2 & $\mathrm{~S}$ & 52 & 21 & 148 & 394 & 95 & 56 \\
\hline Right & Sud & 1 & $\mathrm{~S}$ & 57 & 16 & 282 & 344 & 506 & 93 \\
\hline Right & - & 2 & $\mathrm{~F}$ & 75 & 19 & 390 & 156 & 164 & 66 \\
\hline Right & $\begin{array}{l}\text { C.esophage } \\
\text { i/COPD }\end{array}$ & & $S$ & 75 & 9 & 346 & 86 & 606 & 151 \\
\hline Left & $\begin{array}{l}\text { AMI/NIDD } \\
\mathrm{M}\end{array}$ & & $S$ & 63 & 16 & 254 & 361 & 271 & 127 \\
\hline Left & AMI & 3 & $\mathrm{~F}$ & 80 & 19 & 197 & 255 & 122 & 52 \\
\hline $\begin{array}{l}\text { Mean } \\
\text { (range) }\end{array}$ & & & & $\begin{array}{l}67.0 \\
(52-80)\end{array}$ & $\begin{array}{l}16.7 \\
(9-21)\end{array}$ & $\begin{array}{l}269 \\
(148-390)\end{array}$ & $\begin{array}{l}266 \\
(86-394)\end{array}$ & $\begin{array}{l}294 \\
(95-606)\end{array}$ & $\begin{array}{l}83 \\
(52-151)\end{array}$ \\
\hline
\end{tabular}

Sud: Sudden unexpected death, F: Formalin, A: Acetic acid, S: Stieves Fixative (formalin, mercuric chloride, acetic acid), COPD: Chronic obstructive pulmonary disease, AMI: acute myocardial infarct, NIDDM: non-insulin dependent diabetes mellitus. 


\section{STATISTICS}

The mean values and coefficient of variation $(\mathrm{CV}=\mathrm{SD} /$ mean given in parentheses) between testes were calculated for each cell type and for testicular weight. The hypothesis that no differences were present in testicular weight, and number of Sertoli and Leydig cells between men younger than 30 and men older than 50 years was tested using an unpaired two-tailed t-test. The data on Leydig cell number was $\log$ transformed in order to obtain normal distribution. The remaining data were normally distributed.

\section{RESULTS}

The mean number of Sertoli and Leydig cells counted per testes was $254(113$ - 394) and 236 (94 606) (see Table 1), respectively.

The estimated CE due to sampling was below $10 \%$ at all sampling levels and the overall estimated CE due to sampling was 0.15 for both Sertoli and Leydig cells. The estimated number of Sertoli cells per testis was $430 \times 10^{6}(0.35)$ and Leydig cell number $117 \times 10^{6}(0.53)$ in males less than 30 years. The corresponding numbers in men older than 50 years were $266 \times 10^{6}(0.46)$ for Sertoli cells and $83 \times 10^{6}$ (0.53) for Leydig cells (Table 1). The difference between number of Sertoli cells in males younger than 30 years of age and older than 50 years was borderline statistically significant $(p=0.052)$ while no difference was seen between the total number of Leydig cells in the two groups $(p=0.22)$. No difference was found with respect to testicular weight $(\mathrm{p}=0.43) \quad$ (Table 1). As seen in figure 1 the biological variation of total Leydig and Sertoli cell number seems to be very high in both groups.

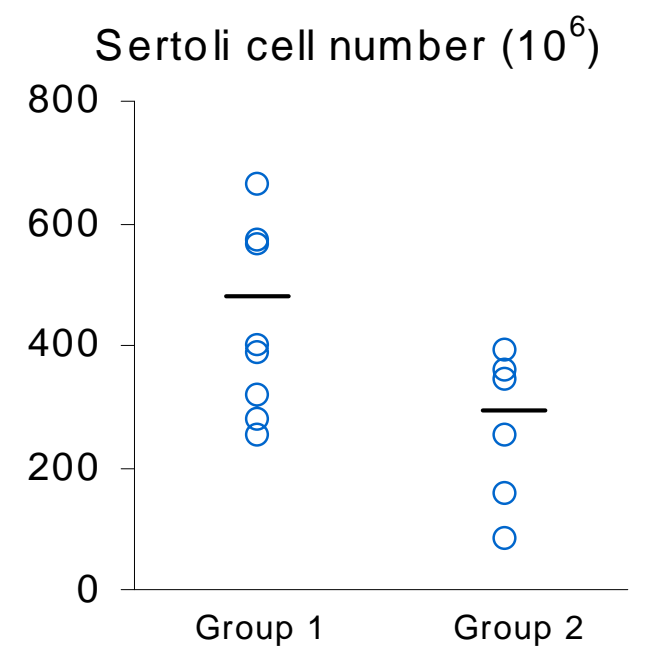

\section{DISCUSSION}

The mean number of Sertoli cells in testes from adult males is approximately $400 \times 10^{6}$ and the number of Leydig cells approximately $90 \times 10^{6}$. The total Leydig and Sertoli cell numbers, estimated by use of stereological methods, differed from the results obtained from most previous studies. The estimated total Sertoli cell numbers have been reported to range from 390 to $3700 \times 10^{6}$ and the total Leydig cell number from 400 to $800 \times 10^{6}$, calculated from twodimensional profile counting (Kaler and Neaves, 1978; Neaves et al., 1985; Cortes et al., 1987; Paniagua et al., 1987). These large ranges may be ascribed to the difficulties in interpretation of results obtained from assumption based designs as previously described (Mendis-Handagama and Ewing, 1990; Mendis-Handagama, 1992). The finding of decreasing number of Sertoli cells with increasing age fits with previous observations while the data on Leydig cells are more conflicting (Kaler and Neaves 1978; Johnson et al., 1984; Neaves et al., 1985; Paniagua et al., 1987; Murray and Meacham 1993). Some investigators claim that Leydig cell hyperthrophy evolves with increasing age while other studies have shown decreasing number of Leydig cells with increasing age (Murray and Meacham 1993).

In the present material we did not find any correlation between the total number of Sertoli or Leydig cells and testis size, probably because of the large biological variation of the total number of these cell types, combined with the rather limited sample size. Furthermore, it should be kept in mind that conclusions based on cross sectional data always may be confounded by secular changes.

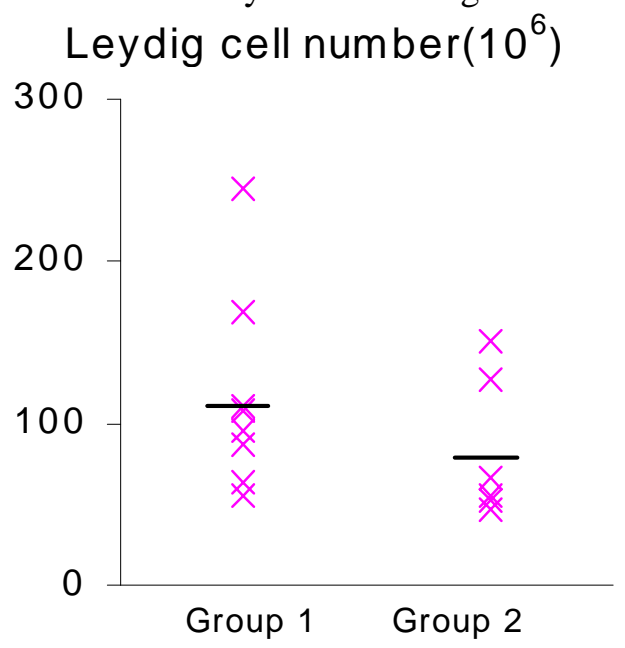

Fig. Estimation of the total number of Sertoli and Leydig cells per human testes in the age-groups: 1: 16-30 years, 2: 50-80 years. 
The imprecision of the estimates of Sertoli and Leydig cells (CE approximately 15\%) should be seen in view of the observation of apparently very large biological variations $(\mathrm{CV}$ of Sertoli cells $>0.34$ and Leydig cells $\mathrm{CV}>0.50$ ). The very large biological variation implies that even the relatively large imprecision of estimates will be acceptable in most clinical situations and that the most important factor in clinical studies comparing groups of patients will be the number of individuals included. In the present study more testes from the older age group are needed before firm conclusions can be made.

In summary, new information about the mechanism of the age-related changes in human testis can be obtained by stereology. In this pilot study decreasing total Sertoli cell number was seen with ageing, while no correlation was detected between total number of Leydig cells and age.

This paper was presented at the $\mathrm{X}^{\text {th }}$ International Congress for Stereology, Melbourne, Australia, 1-4 November 1999.

\section{AKNOWLEDGEMENTS}

The economic support given by The Hartmann Foundation, Direktør Emil Hertz and Wife Inger Hertz Foundation, The NOVO Nordic Foundation, and Fabrikant Einar Willumsens Mindelegat is highly appreciated.

\section{REFERENCES}

Gundersen HJG, Bagger P, Bendtsen TF et al. (1998). The new stereological tools: disector, fractionator, nucleator and point sampled intersepts and their use in pathological research and diagnosis. APMIS 96:857-81.

Haidl G, Jung A, Schill WB (1996). Ageing and sperm function. Hum Reprod 11(3):558-60.

Johnson L, Zane RS, Petty CS, Neaves WB (1984). Quantification of the Human Sertoli cell Population:
Its Distribution, Relation to Germ Cell Numbers, and Age-related Decline. Biol Reprod 31:785-95.

Kaler LW, Neaves WB (1978). Attrition of the human Leydig cell population with advancing age. Anat Rec 192:513-8.

Mendis-Handagama SMLC, Ewing LL (1990). Sources of error in the estimation of Leydig cell numbers in control and atrophied mammalian testes. J Microsc 159:73-82.

Mendis-Handagama SMLC (1992). Estimation error of Leydig cell numbers in atrophied rat testes due to the assumption of spherical nuclei. J Microsc 168:25-32.

Murray MJ, Meacham RB (1993). The effect of age on male reproductive function. World J Urol 11:137-40.

Neaves WB, Johnson L, Petty CS (1985). Age-related Change in Numbers of Other Interstitial Cells in Testis of Adult Men: Evidence Bearing on the Fate of Leydig Cells Lost with Increasing Age. Biol Reprod 33:259-69.

Nieschlag E, Lammers U, Freischem CW et al. (1982). Reproductive Functions in Young Fathers and Grandfathers. JCEM 55(4):676-81.

Paniagua R, Martin A, Nistal M, Amat P (1987). Testicular involution in elderly men: comparison of histologic quantitative studies with hormone patterns. Fertil Steril 47:671-9.

Petersen PM, Pakkenberg B, Giwercman A (1996). The human testis studied using stereological methods. Acta Stereol 15:181-5.

Petersen PM, Giwercman A, Gundersen HJG, Pakkenberg B (2000). Efficient and unbiased tools for quantitating Leydig and Sertoli cells in the testis from biopsies. Image Anal Stereol 19:113-7.

West M, Slomianka L, Gundersen HJG (1991). Unbiased stereological estimation of the total number of neurons in the subdivisions of the rat hippocampus using the optical fractionator. Anat Rec 231:482-97.

Wreford NG (1995). Theory and Practice of Stereological Techniques Applied to the Estimation of Cell Number and Nuclear Volume in the Testis. Microsc Res Tech 32:423-36. 